\title{
Global Mapping of Optometry Workforce
}

Kovin Naidoo

African Vision Research Institute

Pirindhavellie Govender-Poonsamy ( $\nabla$ pirindha@gmail.com )

University of Kwazulu-Natal https://orcid.org/0000-0002-9136-4111

Priya Morjaria

London School of Hygiene and Tropical Medicine International Centre for Eye Health

Sandra S Block

Illinois College of Optometry

Ving Fai Chan

Queen's University Belfast

Ai Chee Yong

Queen's University Belfast

\section{Luigi Bilotto}

University of Montreal School of Optometry: Universite de Montreal Ecole d'optometrie

\section{Research Article}

Keywords: Optometrist, practitioner-to-population ratio, mapping

Posted Date: February 18th, 2022

DOI: https://doi.org/10.21203/rs.3.rs-1286073/v1

License: () (1) This work is licensed under a Creative Commons Attribution 4.0 International License. Read Full License 


\section{Abstract}

BACKGROUND:

The growing global burden of vision impairment makes it imperative that there are appropriately trained human resources. Optometrists play a critical role in alleviating this burden, but the low number of optometrists available or the numbers in different countries has always been a challenge for eye care planning. Despite this, there have been limited studies conducted to quantify the deficits in the number of optometrists globally.

Methods:

A standardised English language questionnaire was used in this cross-sectional study to determine the number and distribution of optometrists globally between February 2017 and May 2020. The survey was translated where necessary and completed by key informants. Using the World Council of Optometry's scope of practice guidelines, optometrists were defined at levels 2 to 4 . Optometrist-to-population ratios were calculated for all countries and regions and compared to targets of 1:50 000 (in developing contexts) or 1:10 000 (in developed contexts).

Results:

An overall response rate of $80.9 \%$ was achieved with responses from 123 of the 152 countries invited. Most (40.7\%) key informants were academics. The total number of optometrists across 21 Global Burden of Disease (GBD) regions was 331,781 as of 2019. Sixty-six (53.7\%) of 123 countries met the 1:50,000 Optometrist-to-population ratio. A strong $(r=0.7)$ direct positive relationship existed between age-standardised prevalences of blindness and mild- and severevision impairment and optometrist-to-population ratios. Strong inverse relationships were observed between country GDP and optometrist-to-population ratio.

Conclusion:

High-income countries met the target for optometrist-to-patient ratios, while low-to-, middle-income countries and low-income countries did not meet the targets. Low optometrist-to-patient ratios were strongly associated with a higher magnitude of blindness and vision impairment.

\section{Background}

Skilled and motivated health workers in sufficient numbers located appropriately in places with unmet needs are critical to deliver effective health services and improve health outcomes.[1] The World Report on Vision highlighted the need for an increase in eye health human resources to address the enormous magnitude of vision and eye health problems[2] - at least 2.2 billion people globally have a vision impairment, of which about 1 billion is preventable or yet to be addressed.[2] While budgets define the ability of countries to provide resources, even with enough finances, the paucity of relevant and appropriately trained human resources, especially optometrists and ophthalmologists,[3] are still a barrier to equitable access to quality eye care. Hence, $90 \%$ of the burden caused by vision impairment is found in developing countries.

Holden et al.[4] estimated that 2.6 billion people were living with myopia, while Frick et al.[5] reported 1.8 billion people living with presbyopia. Holden et al.[4] also established the alarming projection of 5 billion people living with myopia by 2050 . This looming crisis will not only add to the number of people with uncorrected refractive error (URE) but also the number of people with other potentially blinding conditions such as glaucoma, retinal detachment and cataracts. Furthermore, conditions such as diabetic retinopathy, age-related macular degeneration and ailments arising from evolving visually demanding lifestyles (dry eye and binocularity problems) will increase the need for vision care and further amplify a global burden, which already exceeds the human resources for eye health currently available worldwide.

An optometrist, whose core function is detecting, measuring and correcting refractive error, and detecting and managing primary eye care and other conditions of public health concern that add to the global burden of vision impairment, is best placed to contribute to the disease control strategy. The World Council of Optometry defines an optometrist as a healthcare profession that is autonomous, educated, and regulated (licensed or registered). Optometrists are the primary healthcare practitioners of the eye and visual system who provide comprehensive eye and vision care, which includes refraction and dispensing, detection/diagnosis and management of eye disease, and visual system rehabilitation.[6] The importance of optometry was highlighted as an essential workforce in the Universal Eye Health: A Global Action Plan 2014-2019.[7] However, the insufficient number of optometrists means limited screening and reduced accessibility to refractiveservices and optical correction. This has contributed to a large number vision impairment due to URE, a condition that can be safely and inexpensively corrected, yet has become the primary cause of vision impairment.[8]

There have been attempts to quantify the global number of optometrists previously, but they did not provide a robust estimate, partly because these results were generated from a few countries where optometry is well-defined and regulated. The World Council of Optometry, which represents a large proportion of optometrists globally, suggests that it represents 200,000 optometrists from 89 member organisations in over 48 countries.[9] Fricke et al.[10] estimated the number of "functional clinical refractionists" (person who spends $100 \%$ of clinical time providing refraction services) to be 167,013 - a figure that is probably biased towards optometrists. The gross estimate of 300,000 optometrists is often used as the existing number of optometrists globally, but this estimate is not based on a formal evaluation. The estimate is further affected by the varying definitions of the profession of optometry that are used across countries. The result is an inaccurate estimate of an "optometry pool" of eye care workers of varying educational backgrounds providing refraction and/or refractive services at different levels of care and competency. This raises the following questions: i) how many optometry personnel are there globally? ii) where are they distributed, and iii) at what level of competency are they practising? Unless these questions are answered, developing adequate strategies to overcome this burden will be difficult to achieve. 
The primary objectives of this study were to determine the ratio of optometrists to the population according to Global Burden of Disease Regions and its association to the gross domestic product (GDP) per capita and prevalence of blindness and moderate and severe vision impairment. We also investigated the number of training institutes and optometry graduates in the countries. We hypothesised that in countries with a lower number of optometry workforces, the prevalence of blindness and vision impairment would be higher than in countries where the number of optometry workforces is meeting the recommended practitioner-to-population ratio.

\section{Methodology}

A cross-sectional study utilising quantitative methods was conducted from February 2017 to May 2020. Non-random, purposive sampling and a key informant strategy was employed. The key informants were linked to either the World Council of Optometry members, other ophthalmic groups, prominent academics or individuals playing a key role in eye health development. These individuals were invited to complete the survey, which focussed on ascertaining the quantity and distribution of optometrists globally. When necessary, clarification on the survey questions was provided via direct communication, either verbally or via digital communications. A standardised English language questionnaire was designed to obtain the key indicators needed. Concerted efforts were made to reach those countries that initially did not respond. If the original key informant could not respond to the survey, they were asked for referrals to other individuals who could provide the necessary information.

The original English language survey was translated into Spanish, French, and Mandarin for ease of completion for those whose primary language was not English and were not comfortable responding to an English survey. Translators were used to translate the responses to English if they were self-administered in languages other than English. The survey was distributed via an email link (online survey) or on paper or Microsoft Office Word format for internet-limited settings. Respondents provided consent to participate in the survey before answering the specific research questions.

According to the Institute for Health Metric and Evaluation (IHME), there were 200 Global Burden of Disease countries (http://ghdx.healthdata.org/countries). However, 152 countries were included in the survey, with 48 countries being excluded due to unobtainable key informants as optometry does not formally exist in all countries. Data collected was reviewed, missing data were identified, and key informants were approached to provide the missing data or clarification, where possible.

The main questions presented to respondents were as follows (see Appendix 1 for further details):

1. What was the source of the information provided?

2. What was the number of professionals functioning at the various WCO Competency levels?

3. How many Optometry training institutions were there in the country?

4. How many optometrists did the optometry training institutions graduate per annum?

5. Was Optometry regulated?

The WCO Competency Model was used to define optometry with four categories of services which were:

1. Category 1: Optical Technology Services: Management and dispensing of ophthalmic lenses, ophthalmic frames and other ophthalmic devices that correct defects of the visual system

2. Category 2: Visual Function Services: Investigation, examination, measurement, diagnosis and correction/management of defects of the visual system

3. Category 3: Ocular Diagnostic Services: Investigation, examination and evaluation of the eye and adnexa and associated systemic factors to detect, diagnose and manage the disease

4. Category 4: Ocular Therapeutic Services: Use of pharmaceutical agents and other procedures to manage ocular conditions/disease

Based on this optometry workforce scope of practice, practitioners practising at Category 2 and above were considered to be defined as Optometrists. Our analysis excluded practitioners functioning at Category 1, who are based solely on dispensing spectacles, without investigation, examination, measurement, diagnosis and correction or management of the visual system defects.

Data was captured in a Microsoft Excel spreadsheet and then exported to Statistical Package for the Social Sciences (SPSS v26.0) for data cleaning and subsequent analysis. Descriptive statistics in the forms of frequencies and distributions were used to assess the response rates across $21 \mathrm{GBD}$ regions, key informant's background and the source of information, country's capacity in training optometrists, regulation and continuous medical education in the respective country. The number of optometrists and the total population in the country were used to calculate the optometrist-to-population ratios, regionally and by country. Spearman's correlation analysis was used to test the association between the optometrist-to-population ratio and the demographic variables such as country's GDP per capita, the age-standardised prevalence of blindness and moderate and severe vision impairment (MSVI), with the significance level set at $5 \%$. Ethics approval was obtained from the Human and Social Sciences Research Ethics Committee (Reference number: HSS/2135/016) from the University of KwaZulu-Natal, Durban, South Africa.

\section{Results}

\section{Survey response rate}

We received responses from 123 of the 152 countries invited for the survey, resulting in an overall response rate of $80.9 \%$. Forty-eight of the 200 GBD countries were excluded due to unobtainable key informants. Table 1 shows the distribution of responses of countries by GBD region. Regions with lower response rates 
were mainly from Sub-Saharan Africa, with the Central region being the lowest with $50.0 \%$, followed by Western and Southern regions with $63.2 \%$ and $66.7 \%$, respectively.

Table 1

Total number of countries included in the survey and the response rates ( $n=152$ countries)

\begin{tabular}{|c|c|c|c|}
\hline Global Burden of Disease Regions & Total number of countries included* & Total number of responded countries & Response rate (\%) \\
\hline Andean Latin America & 3 & 3 & 100 \\
\hline Australasia & 2 & 2 & 100 \\
\hline Caribbean & 16 & 11 & 68.8 \\
\hline Central Asia & 2 & 2 & 100 \\
\hline Central Europe & 5 & 5 & 100 \\
\hline Central Latin America & 9 & 6 & 66.7 \\
\hline Central Sub-Saharan Africa & 4 & 2 & 50.0 \\
\hline East Asia & 2 & 2 & 100 \\
\hline Eastern Europe & 4 & 3 & 75.0 \\
\hline Eastern Sub-Saharan Africa & 15 & 13 & 86.7 \\
\hline High-income Asia Pacific & 4 & 3 & 75.0 \\
\hline High-income North America & 2 & 2 & 100 \\
\hline North Africa and Middle East & 14 & 10 & 71.4 \\
\hline Oceania & 8 & 7 & 87.5 \\
\hline South Asia & 4 & 3 & 75. \\
\hline Southeast Asia & 11 & 11 & 100. \\
\hline Southern Latin America & 3 & 3 & 100. \\
\hline Southern Sub-Saharan Africa & 6 & 4 & 66.7 \\
\hline Tropical Latin America & 2 & 2 & 100. \\
\hline Western Europe & 17 & 17 & 100. \\
\hline Western Sub-Saharan Africa & 19 & 12 & 63.2 \\
\hline TOT/AL & 152 & 123 & 80.9 \\
\hline
\end{tabular}

\section{Key informant's background and source of information}

Most respondents were affiliated with universities or research institutes (53 countries, $43.1 \%$ ) or professional associations (42 countries, $34.1 \%$ ) (Table 2 ). Most key informants were academics (40.7\%), followed by association representatives (30.9\%). More than half of the respondents' information (55.3\%) was from government sources, primarily the Ministry of Health, Health Council Registry, and Medical Council Registry. 


\begin{tabular}{|c|c|c|c|}
\hline & & $\begin{array}{l}\text { Number of } \\
\text { countries }\end{array}$ & $\%$ \\
\hline \multirow[t]{9}{*}{ Affiliations } & University/Research Institute & 53 & 43.1 \\
\hline & Association & 42 & 34.1 \\
\hline & $\begin{array}{l}\text { Association of Optometry, Association of Optician, College of Optometrist, Society of Technical Opticians, College of } \\
\text { Opticians, Contactologists and Optometers, Ophthalmologist's Society }\end{array}$ & & \\
\hline & Government Ministerial Unit & 14 & 11.4 \\
\hline & Ministry of Health, Ministry of Education, Medical Council, Optical Council & & \\
\hline & Non-governmental Organisation & 11 & 9.0 \\
\hline & Optical Practice & 2 & 1.6 \\
\hline & Did not specify & 1 & 0.8 \\
\hline & Total & 123 & 100 \\
\hline \multirow{12}{*}{$\begin{array}{l}\text { Key } \\
\text { informants }\end{array}$} & Academia & 50 & 40.7 \\
\hline & University Director, Head of Department, Dean of Faculty, Lecturer, Professor & & \\
\hline & Association Representative & 38 & 30.9 \\
\hline & Director, CEO, Chairman, Chair, President, Secretary, Member, Coordinator & & \\
\hline & Eye Care Personnel & 15 & 12.2 \\
\hline & Optometrist, Ophthalmologist & & \\
\hline & Government Representative & 9 & 7.3 \\
\hline & National Eye Care Coordinator, Council Director, Council Secretary, Council Member, Diplomat, Coordinator & & \\
\hline & Non-governmental Organisation Representative & 9 & 7.3 \\
\hline & Foundation Director, Foundation Manager, Country Director, Programme Manager & & \\
\hline & Did not specify & 2 & 1.6 \\
\hline & Total & 123 & 100 \\
\hline \multirow{11}{*}{$\begin{array}{l}\text { Source of } \\
\text { Information }\end{array}$} & Government & 68 & 55.3 \\
\hline & $\begin{array}{l}\text { Ministry of Health, Health Council Register, Medical Council Register, Health Practitioner Registration Agency, Ministry } \\
\text { of Public Health, Patient Safety Authority }\end{array}$ & & \\
\hline & Associations & 11 & 8.9 \\
\hline & European Academy of Optics and Optometry, College Graduation List, Eye Institute, School of Optometry Register & 8 & 6.5 \\
\hline & WHO Reports & 2 & 1.6 \\
\hline & Biblioteca Regional de Medicina (BIREME), Pan American Health Organisation (PAHO WHO ECSAR) & & \\
\hline & IAPB Vision Atlas & 1 & 0.8 \\
\hline & Other Sources & 21 & 17.1 \\
\hline & $\begin{array}{l}\text { On the ground research, desktop search, public health study, NGO database, general information, self, private email, } \\
\text { personal awareness, trade register, hospital data, manufacturers, syllabus curriculum. }\end{array}$ & & \\
\hline & Did not specify & 12 & 9.8 \\
\hline & Total & 123 & 100 \\
\hline
\end{tabular}

\section{The distribution of optometrists across Global Burden of Disease Regions}

As guided by the World Council of Optometry, practitioners practising at Category 2 to 4 were considered to be optometrists. The reported number of optometrists across $21 \mathrm{GBD}$ regions was 331,781 as of the year 2019 , covering $88.5 \%$ of the global population (6.79 billion in 123 countries) (Table 3 ). The number of Category 4 optometrists were three times less than those practising at Category $2(55,427$ and 169,076 , respectively). Seven regions reported no optometrists practising at Category 4 referring to Andean Latin America, Southern Latin America, Tropical Latin America, Central Asia, Central and Eastern Europe, and High-income Asia Pacific.

Considering the optometrist-to- opulation ratio, globally, one optometrist is serving an average of 20,479 persons. The unequal workforce distribution across countries and regions showed that in Central Sub-Saharan Africa, one optometrist serves 1,198,141 persons, compared to 3,877 populations in Western Europe. Among the 123 countries, 66 (53.7\%) met the World Health Organisation recommended 1 optometrist to 50,000 persons target (1: 50,000),[11] while 
only 33 (26.8\%) reached the 1: 10,000 target as previously found in many developed countries.[12] All the countries in Australasia, Central Europe, High-income Asia Pacific, and High-income North America regions achieved both the recommended targets (Table 3). 
Table 3

The number of optometrists and the ratio of optometrists to the population according to Global Burden of Disease regions

\begin{tabular}{|c|c|c|c|c|c|c|c|c|c|c|}
\hline \multirow{2}{*}{$\begin{array}{l}\text { Global } \\
\text { Burden of } \\
\text { Disease } \\
\text { Regions }\end{array}$} & \multirow[t]{2}{*}{$\begin{array}{l}\text { Number } \\
\text { of } \\
\text { countries }\end{array}$} & \multicolumn{3}{|c|}{$\begin{array}{l}\text { Number of optometrists } \\
\text { according to the scope of } \\
\text { practice }\end{array}$} & \multirow[t]{2}{*}{$\begin{array}{l}\text { Total } \\
\text { number of } \\
\text { optometrists }\end{array}$} & \multirow[t]{2}{*}{$\begin{array}{l}2019 \text { Total } \\
\text { populations } \\
\text { (thousands)* }\end{array}$} & \multirow{2}{*}{$\begin{array}{l}\text { Optometrist } \\
\text { to } \\
\text { population } \\
\text { ratio }\end{array}$} & \multirow{2}{*}{$\begin{array}{l}\text { Number of } \\
\text { optometrists } \\
\text { to reach the } \\
\text { recommended } \\
1 \text { optometrist } \\
\text { to } 50000 \\
\text { population } \\
(1: 50000) \\
\text { target }\end{array}$} & \multirow{2}{*}{$\begin{array}{l}\text { Total number } \\
\text { of countries } \\
\text { reached the } \\
\text { recommended } \\
1: 50000 \\
\text { target }\end{array}$} & \multirow{2}{*}{$\begin{array}{l}\text { Number } \\
\text { optome } \\
\text { to reach } \\
\text { recomm } \\
1 \text { optom } \\
\text { to } 1000 \\
\text { populati } \\
\text { (1:1000 } \\
\text { target }\end{array}$} \\
\hline & & $\begin{array}{l}\text { Category } \\
2\end{array}$ & $\begin{array}{l}\text { Category } \\
3\end{array}$ & $\begin{array}{l}\text { Category } \\
4\end{array}$ & & & & & & \\
\hline $\begin{array}{l}\text { Andean } \\
\text { Latin } \\
\text { America }\end{array}$ & 3 & 3056 & 40 & 0 & 3096 & 61237 & 1: 19779 & 1225 & 1 & 6123 \\
\hline Australasia & 2 & 0 & 2260 & 3736 & 5996 & 29985 & 1: 5001 & 600 & 2 & 2998 \\
\hline Caribbean & 11 & 40 & 408 & 56 & 504 & 31467 & $1: 62435$ & 629 & 8 & 3147 \\
\hline $\begin{array}{l}\text { Central } \\
\text { Asia }\end{array}$ & 2 & 0 & 0 & 0 & 0 & 21776 & $-* \star$ & 436 & 0 & 2178 \\
\hline $\begin{array}{l}\text { Central } \\
\text { Europe }\end{array}$ & 5 & 2765 & 900 & 0 & 3665 & 67341 & 1: 18374 & 1348 & 5 & 6735 \\
\hline $\begin{array}{l}\text { Central } \\
\text { Latin } \\
\text { America }\end{array}$ & 6 & 928 & 12093 & 2491 & 15512 & 213544 & 1: 13766 & 4271 & 5 & 21354 \\
\hline $\begin{array}{l}\text { Central } \\
\text { Sub- } \\
\text { Saharan } \\
\text { Africa }\end{array}$ & 2 & 97 & 0 & 2 & 99 & 118616 & 1: 1198141 & 2373 & 0 & 11862 \\
\hline East Asia & 2 & 2500 & 800 & 900 & 4200 & 1457558 & 1: 34704 & 29151 & 0 & 145755 \\
\hline $\begin{array}{l}\text { Eastern } \\
\text { Europe }\end{array}$ & 3 & 2700 & 2 & 0 & 2702 & 151241 & 1: 55974 & 3025 & 1 & 15124 \\
\hline $\begin{array}{l}\text { Eastern } \\
\text { Sub- } \\
\text { Saharan } \\
\text { Africa }\end{array}$ & 13 & 946 & 2667 & 603 & 4216 & 436107 & 1: 103441 & 8722 & 2 & 43610 \\
\hline $\begin{array}{l}\text { High- } \\
\text { income } \\
\text { Asia } \\
\text { Pacific }\end{array}$ & 3 & 47197 & 100 & 0 & 47297 & 183933 & 1: 3889 & 3678 & 3 & 18393 \\
\hline $\begin{array}{l}\text { High- } \\
\text { income } \\
\text { North } \\
\text { America }\end{array}$ & 2 & 0 & 0 & 42720 & 42720 & 366476 & 1: 8679 & 7329 & 2 & 36648 \\
\hline $\begin{array}{l}\text { North } \\
\text { Africa and } \\
\text { Middle } \\
\text { East }\end{array}$ & 10 & 3120 & 4095 & 11 & 7231 & 227327 & 1: 31438 & 4547 & 6 & 23733 \\
\hline Oceania & 7 & 16 & 16 & 7 & 39 & 10803 & 1: 277000 & 216 & 3 & 1081 \\
\hline South Asia & 3 & 38950 & 13590 & 1078 & 53618 & 1611592 & 1: 30057 & 32232 & 2 & 161159 \\
\hline $\begin{array}{l}\text { Southeast } \\
\text { Asia }\end{array}$ & 11 & 3994 & 13284 & 38 & 17346 & 624422 & 1: 35998 & 12488 & 6 & 62442 \\
\hline $\begin{array}{l}\text { Southern } \\
\text { Latin } \\
\text { America }\end{array}$ & 3 & 424 & 720 & 0 & 1144 & 67195 & 1: 58737 & 1344 & 1 & 6720 \\
\hline $\begin{array}{l}\text { Southern } \\
\text { Sub- } \\
\text { Saharan } \\
\text { Africa }\end{array}$ & 4 & 10 & 3984 & 32 & 4026 & 77632 & 1: 19283 & 1553 & 1 & 7764 \\
\hline $\begin{array}{l}\text { Tropical } \\
\text { Latin } \\
\text { America }\end{array}$ & 2 & 2000 & 1500 & 0 & 3500 & 218095 & 1: 62313 & 4362 & 0 & 21810 \\
\hline
\end{tabular}

*Source: United Nation World Population Prospect 2019 (https://population.un.org/wpp/Download/Standard/Population/)

** There was no optometrist in the Central Asia region.

***Refer to Online Supplementary File 2 for details at the country level. 


\begin{tabular}{|c|c|c|c|c|c|c|c|c|c|c|}
\hline \multirow{2}{*}{$\begin{array}{l}\text { Global } \\
\text { Burden of } \\
\text { Disease } \\
\text { Regions }\end{array}$} & \multirow[t]{2}{*}{$\begin{array}{l}\text { Number } \\
\text { of } \\
\text { countries }\end{array}$} & \multicolumn{3}{|c|}{$\begin{array}{l}\text { Number of optometrists } \\
\text { according to the scope of } \\
\text { practice }\end{array}$} & \multirow[t]{2}{*}{$\begin{array}{l}\text { Total } \\
\text { number of } \\
\text { optometrists }\end{array}$} & \multirow[t]{2}{*}{$\begin{array}{l}2019 \text { Total } \\
\text { populations } \\
\text { (thousands)* }\end{array}$} & \multirow{2}{*}{$\begin{array}{l}\text { Optometrist } \\
\text { to } \\
\text { population } \\
\text { ratio }\end{array}$} & \multirow{2}{*}{$\begin{array}{l}\text { Number of } \\
\text { optometrists } \\
\text { to reach the } \\
\text { recommended } \\
1 \text { optometrist } \\
\text { to } 50000 \\
\text { population } \\
(1: 50000) \\
\text { target }\end{array}$} & \multirow{2}{*}{$\begin{array}{l}\text { Total number } \\
\text { of countries } \\
\text { reached the } \\
\text { recommended } \\
1: 50000 \\
\text { target }\end{array}$} & \multirow{2}{*}{$\begin{array}{l}\text { Number } \\
\text { optomet } \\
\text { to reach } \\
\text { recomm } \\
1 \text { optom } \\
\text { to } 1000 \text { c } \\
\text { populati } \\
(1: 1000 \text { C } \\
\text { target }\end{array}$} \\
\hline & & $\begin{array}{l}\text { Category } \\
2\end{array}$ & $\begin{array}{l}\text { Category } \\
3\end{array}$ & $\begin{array}{l}\text { Category } \\
4\end{array}$ & & & & & & \\
\hline $\begin{array}{l}\text { Western } \\
\text { Europe }\end{array}$ & 17 & 59831 & 50364 & 840 & 111035 & 430465 & 1: 3877 & 8609 & 17 & 43047 \\
\hline $\begin{array}{l}\text { Western } \\
\text { Sub- } \\
\text { Saharan } \\
\text { Africa }\end{array}$ & 12 & 508 & 414 & 2912 & 3834 & 387793 & 1: 101146 & 7756 & 1 & 38780 \\
\hline TOTAL & 123 & 169076 & 107272 & 55427 & 331781 & 6794609 & 1: 20479 & 135892 & $66(53.7 \%)$ & 679461 \\
\hline
\end{tabular}

*Source: United Nation World Population Prospect 2019 (https://population.un.org/wpp/Download/Standard/Population/)

** There was no optometrist in the Central Asia region.

$\star \star \star$ Refer to Online Supplementary File 2 for details at the country level.

\section{Relationship between the optometrist-to-population ratio and the country demographic characteristics}

A higher age-standardised prevalence of blindness was significantly associated with a lower optometrist-to-population ratio at the country level ( $\mathrm{p}<0.001$, $r=0.721$ ) (Figure 1). This correlation was considered strong as the $r$-value was more than 0.7. A similar finding was reported for the age-standardised prevalence of mild and severe vision impairment, where a significant moderate direct positive relationship between the burden of disease and the optometristto-population ratio was observed $(p<0.001, r=0.636)$ (Figure 2$)$.

A significant inverse relationship was observed between the country gross domestic product per capita and the optometrist-to-population ratio ( $p<0.001$, $r=-0.770$ ) (Figure 3). Lower country gross domestic product per capita is correlated with a greater deficit of optometrists in the country.

\section{Country's capacity in training optometrist}

A total of 19,265 optometrists graduate from 123 countries annually (Table 4). Western Europe trained the highest number of optometrists among the $21 \mathrm{GBD}$ regions (4,594 graduates), followed by South Asia (4,492 graduates), High-income Asia Pacific (2,160 graduates) and East Asia (2,100 graduates). Three regions did not have institutions within the countries to train optometrists, specifically, Central Asia, Central Sub-Saharan Africa, ad Oceania.

\section{Country's regulation on optometry and continuous medical education}

Out of the 123 countries, less than half of the surveyed countries ( $n=54,43.9 \%$ ) regulated optometry as an eye care professional. (Table 4$)$ Optometry was recognised in all the countries in Australasia, high-income Asia Pacific and High-income North America regions. Forty-two countries (34.1\%) imposed mandatory continuing professional education to maintain optometrists' competency level and further equip them with up-to-date practices. 
Table 4

The number of training institutions, graduates per annum, countries with regulation and continuing medical education according to Global Burden of Disease

\begin{tabular}{|c|c|c|c|c|c|c|c|c|c|c|}
\hline \multirow{2}{*}{$\begin{array}{l}\text { Global } \\
\text { Burden of } \\
\text { Disease } \\
\text { Regions }\end{array}$} & \multirow{2}{*}{$\begin{array}{l}\text { Number } \\
\text { of } \\
\text { countries }\end{array}$} & \multicolumn{3}{|c|}{$\begin{array}{l}\text { Number of institutions providing } \\
\text { training }\end{array}$} & \multicolumn{3}{|c|}{ Number of graduates per annum } & \multirow{2}{*}{$\begin{array}{l}\text { Total } \\
\text { number } \\
\text { of } \\
\text { graduates } \\
\text { per } \\
\text { annum }\end{array}$} & \multirow{2}{*}{$\begin{array}{l}\text { Total number } \\
\text { of countries } \\
\text { with the } \\
\text { optometry } \\
\text { profession } \\
\text { regulated }\end{array}$} & \multirow{2}{*}{$\begin{array}{l}\text { Total number of } \\
\text { countries with } \\
\text { mandatory } \\
\text { continuing medical } \\
\text { education for } \\
\text { optometrists }\end{array}$} \\
\hline & & $\begin{array}{l}\text { Category } \\
2\end{array}$ & $\begin{array}{l}\text { Category } \\
3\end{array}$ & $\begin{array}{l}\text { Category } \\
4\end{array}$ & $\begin{array}{l}\text { Category } \\
2\end{array}$ & $\begin{array}{l}\text { Category } \\
3\end{array}$ & $\begin{array}{l}\text { Category } \\
4\end{array}$ & & & \\
\hline $\begin{array}{l}\text { Andean } \\
\text { Latin } \\
\text { America }\end{array}$ & 3 & 6 & 1 & 0 & 71 & 0 & 0 & 71 & 1 & 0 \\
\hline Australasia & 2 & 0 & 1 & 7 & 0 & 55 & 385 & 440 & 2 & 2 \\
\hline Caribbean & 11 & 0 & 4 & 1 & 0 & 80 & 50 & 130 & 6 & 5 \\
\hline Central Asia & 2 & 0 & 0 & 0 & 0 & 0 & 0 & 0 & 0 & 0 \\
\hline $\begin{array}{l}\text { Central } \\
\text { Europe }\end{array}$ & 5 & 13 & 3 & 0 & 315 & 55 & 0 & 370 & 2 & 2 \\
\hline $\begin{array}{l}\text { Central Latin } \\
\text { America }\end{array}$ & 6 & 4 & 13 & 25 & 125 & 102 & 500 & 727 & 4 & 2 \\
\hline $\begin{array}{l}\text { Central Sub- } \\
\text { Saharan } \\
\text { Africa }\end{array}$ & 2 & 0 & 0 & 0 & 0 & 0 & 0 & 0 & 0 & 0 \\
\hline East Asia & 2 & 28 & 28 & 19 & 1500 & 200 & 400 & 2100 & 0 & 0 \\
\hline $\begin{array}{l}\text { Eastern } \\
\text { Europe }\end{array}$ & 3 & 5 & 0 & 0 & 70 & 0 & 0 & 70 & 1 & 1 \\
\hline $\begin{array}{l}\text { Eastern Sub- } \\
\text { Saharan } \\
\text { Africa }\end{array}$ & 13 & 5 & 6 & 9 & 45 & 58 & 150 & 253 & 7 & 6 \\
\hline $\begin{array}{l}\text { High-income } \\
\text { Asia Pacific }\end{array}$ & 3 & 71 & 0 & 0 & 2160 & 0 & 0 & 2160 & 3 & 2 \\
\hline $\begin{array}{l}\text { High-income } \\
\text { North } \\
\text { America }\end{array}$ & 2 & 0 & 0 & 23 & 0 & 0 & 1900 & 1900 & 2 & 2 \\
\hline $\begin{array}{l}\text { North Africa } \\
\text { and Middle } \\
\text { East }\end{array}$ & 10 & 4 & 12 & 0 & 90 & 300 & 0 & 390 & 5 & 3 \\
\hline Oceania & 7 & 0 & 0 & 0 & 0 & 0 & 0 & 0 & 2 & 3 \\
\hline South Asia & 3 & 86 & 118 & 12 & 1600 & 2570 & 322 & 4492 & 1 & 0 \\
\hline $\begin{array}{l}\text { Southeast } \\
\text { Asia }\end{array}$ & 11 & 10 & 34 & 1 & 279 & 680 & 0 & 959 & 4 & 3 \\
\hline $\begin{array}{l}\text { Southern } \\
\text { Latin } \\
\text { America }\end{array}$ & 3 & 2 & 12 & 0 & 11 & 80 & 0 & 91 & 1 & 0 \\
\hline $\begin{array}{l}\text { Southern } \\
\text { Sub-Saharan } \\
\text { Africa }\end{array}$ & 4 & 0 & 6 & 1 & 0 & 155 & 0 & 155 & 2 & 2 \\
\hline $\begin{array}{l}\text { Tropical } \\
\text { Latin } \\
\text { America }\end{array}$ & 2 & 2 & 3 & 0 & 0 & 200 & 0 & 200 & 0 & 0 \\
\hline $\begin{array}{l}\text { Western } \\
\text { Europe }\end{array}$ & 17 & 18 & 51 & 5 & 2324 & 2180 & 90 & 4594 & 8 & 6 \\
\hline $\begin{array}{l}\text { Western Sub- } \\
\text { Saharan } \\
\text { Africa }\end{array}$ & 12 & 6 & 2 & 7 & 83 & 80 & 0 & 163 & 3 & 3 \\
\hline TOTAL & 123 & 260 & 294 & 110 & 8673 & 6795 & 3797 & 19265 & $54(43.9 \%)$ & $42(34.1 \%)$ \\
\hline
\end{tabular}

\section{Discussion}

Our study quantified the number of optometrists functioning according to the WCO competency level. The optometrist-to-population ratio globally of one optometrist to 20,479 persons appears reasonable when viewed in the developing world context (1:50,000 recommended ratio)[11]. However, this ratio masks the unequal distribution of the workforce across countries or regions. Central Sub-Saharan Africa, for example, is serving 1,198,141 populations, compared to 
3,877 populations in Western Europe. Approximately half of the countries (53.7\%) met the 1: 50,000 ratio, with all high-income regions meeting the 1: 10,000 ratio.

Anecdotal evidence suggests that the ratio of optometrists to population is critically low in rural and outlying areas and magnifies the deficits displayed in our data. This paucity of optometrists in the developing world is further accentuated when one considers intra-country variations whereby optometrists, like most eye care providers are confined to the major cities. While producing more optometrists is imperative to address the unequal distribution, the workforce must be more effectively distributed, a major challenge given the lack of incentives[13] and facilities in rural and remote areas, making recruitment difficult.

Developing an adequate number for the workforce is a complex task due to numerous factors, including key elements such as the lack of educators, the length of training for professionals, regulatory barriers, and the cost of setting up training institutions. However, Thompson et al. showed that implementing an optometry program de novo in a developing country is cost-effective,[14] which in the best case scenario reaches self-sufficiency in 10-12 years post setup, using conservative approaches and restricted means. A lower country GDP per capita is correlated with a greater shortage of optometrists in countries. As such, resources may not always be available for the establishment of schools of optometry. Strong advocacy supported by a robust evidence base such as the impact of poor vision on productivity[15-17] or learning[18-20], which is documented, is needed to make a case for the value of optometry school development. International collaboration needs to be mobilised to ensure that academic, logistical and material support is provided for new schools, and new policy formulation needs to overcome regulatory barriers. However, the current status in the low-income countries indicates that the deficits seen in the number of optometrists will not be addressed soon. As few new optometrists are being trained, innovative strategies that encompass the following need ot be explored:

- Team approach: While vision screening is done at a primary level by allied health professionals, linking optometrists in the referral pathway is imperative to ensure a continuum of care. Optical assistants/technicians assisting in refractive services by doing some preliminary testing can help increase the effectiveness of optometrists. Similarly, the referral pathway for available optometrists to ophthalmologists and other specialty services for a higher level of care needs to be facilitated. In adopting a team approach, optometrists can provide the care needed by three types of patients: those who need ongoing care, those at early-stage disease and those with symptomatic conditions without vision impairment but still need services.[21]

- Technology: Strategies such as using more cost-effective tools to increase the quality of care and increase the output of optometrists needs to be explored. Furthermore, the optometry workforce needs to be mobilised to reach outlying rural areas via outreach activity or supporting social businesses in under-developed areas. Tele-health overseen by optometry may support distance monitoring and oversight to potentially provide a greater reach for the profession. These strategies, however, need to be carefully developed without compromising the quality of care.

- Upskilling: In countries where optometry is not developed, post-graduate and continuing professional education must be explored to expand the knowledge and skills of existing cadres so that they can be integrated into the optometry profession. This takes on increasing importance in an era where other morbidities such as diabetic retinopathy and glaucoma are becoming a significant threat to visual health if detection and treatment are delayed.

The World Report on Vision states that at least 1 billion people in the world with vision impairment could have been prevented or have yet to be addressed.[2] Of this, almost 950 million is related to refractive error and presbyopia; both are key responsibilities of optometrists to address. The correlation between low numbers of optometrists and a high prevalence of vision impairment and blindness in regions thus indicates that unless urgent action is taken to increase the number of optometrists trained and deployed to underserved areas in low-income countries, plans to eliminate preventable vision impairment will remain elusive. In addition, implementing comprehensive eye care will be difficult to provide as this requires a team, with the optometrists as a critical component of that team.

Although optometrists were trained and competent in delivering primary eye care to the populations, more than half of the surveyed countries did not officially regulate this profession as part of the health system. This implies that advocacy work must be undertaken to make optometry visible to the governing bodies, the relevant authorities, and the public. The recognition of the profession is vital to enable funding priority in training an adequate number for the optometry workforce to support the population's needs in eye health services.

While this study had a good response rate, one limitation was the inability to reach all countries where optometry is practised, or where optometric care is delivered under a different technical terminology. There is a need to expand this data collection to all of the 200 GBD countries. However, the data identifies the divide between the low-income and high-income regions and countries in the training and deployment of optometrists. A follow-up study will be conducted to ensure that more countries are included.

\section{Conclusion}

Our study found that high-income countries met the target for optometrist-to-patient ratios. Low-to-middle-income countries and low-income countries did not only fail to meet the targets, but they are also far from reaching them. The low optometrist-to-patient ratios are strongly associated with a higher magnitude of blindness and vision impairment.

The number of optometrists worldwide is increasing, but gaps remain in numerous areas around the world. Unless these gaps are addressed, we will not make a significant contribution towards achieving targets related to Universal Health Coverage and the Sustainable Development Goals outlined by the United Nations. According to the World Report on Vision, "Everyone, if they live long enough, will experience at least one eye condition in their lifetime. For example, many people will have had conjunctivitis as a child, will need spectacles due to presbyopia sometime after 40 years of age, or require cataract surgery later in life." This statement amplifies the need for eye care globally. With the lack of optometrists in the low-income areas of the world, optometry training and output will have to be significantly accelerated or upscaled to address the increased demand for eye care. 


\section{Declarations}

Ethics approval and consent to participate: A statement of ethics committee and the corresponding

reference number has been included in the manuscript. A statement of consent to participate was

included in the survey.

Consent for publication: All authors grant the publisher the permission to publish the manuscript.

Availability of data and materials: All data generated or analysed during this study are included in this

published article (and its supplementary information files).

Competing interests: None

Funding: Brien Holden Vision Institute, World Council of Optometry and African Vision Research

Institute.

Authors contributions: K.N., P.GP., P.M., S.S.B., V.F.C., L.B. contributed to the design and

implementation of the research; K.N., P.GP, A.C. wrote the first draft; all authors contributed to the review and editing of the manuscript.

Acknoweldgements: We would like to acknowledge the respondents on the survey for their

contributions

\section{References}

1. World Health Organization. Increasing Access to Health Workers in Remote and Rural Areas through Improved Retention: Global Policy recommendations. Geneva, Switzerland; 2010.

2. World Health Organization. World Health Organisation. World report on vision. World Heal. Organ. Geneva; 2019.

3. Resnikoff S, Lansingh VC, Washburn L, Felch W, Gauthier T-M, Taylor HR, et al. Estimated number of ophthalmologists worldwide (International Council of Ophthalmology update): will we meet the needs? Br J Ophthalmol. 2020;104:588-92.

4. Holden BA, Fricke TR, Wilson DA, Jong M, Naidoo KS, Sankaridurg P, et al. Global Prevalence of Myopia and High Myopia and Temporal Trends from 2000 through 2050. Ophthalmology. 2016;123:1036-42.

5. Fricke T, Tahhan N, Resnikoff S, Papas E, Burnett A, Ho S, et al. Global prevalence of presbyopia and vision impairment from uncorrected presbyopia: systematic review, meta-analysis, and modelling. Ophthalmology. 2018;125:1492-9.

6. World Council of Optometry. WCO's Concept of Optometry [Internet]. 2020 [cited 2020 Oct 20]. Available from: https://worldcouncilofoptometry.info/concept-of-optometry/.

7. World Health Organization. Universal eye health: a global action plan 2014-2019. 2013.

8. Flaxman SR, Bourne RRAA, Resnikoff S, Ackland P, Braithwaite T, Cicinelli MV, et al. Global causes of blindness and distance vision impairment $1990-$ 2020: a systematic review and meta-analysis. Lancet Glob Heal Elsevier. 2017;5:e1221-34.

9. World Health Organization. Global Health Workforce Alliance: The World Council of Optometry (WCO) [Internet]. Memb. profile. 2021 [cited 2021 May 6]. Available from: https://www.who.int/workforcealliance/members_partners/member_list/wcoptometry/en/.

10. Fricke T, Holden B, Wilson D, Al. E. Global cost of correcting vision impairment from uncorrected refractive error. Bull World Health Organ. 2012;90:728-39.

11. World Health Organization. VISION2020 THE RIGHT TO SIGHT Global initiative for the elimination of avoidable blindness - Action Plan $2006-2011.2007$.

12. Holden B, Resnikoff S. The role of optometry in vision 2020. J Community Eye Heal. 2002;15:33-6.

13. Ramson P, Govender P, Naidoo K. Recruitment and retention strategies for public sector optometrists in KwaZulu-Natal Province, South Africa. African Vis Eye Heal. 2016;75:a349.

14. Thompson S, Naidoo K, Harris G, Bilotto L, Ferrão J, Loughman J. The development of a public optometry system in Mozambique: a Cost Benefit Analysis. BMC Health Serv Res. 2014;14:422-9.

15. Naidoo KS, Fricke TR, Frick KD, Jong M, Naduvilath TJ, Resnikoff S, et al. Potential Lost Productivity Resulting from the Global Burden of Myopia: Systematic Review, Meta-analysis, and Modeling. Ophthalmology. 2019;126:338-46.

16. Smith TST, Frick KD, Holden BA, Fricke TR, Naidoo KS. Potential lost productivity resulting from the global burden of uncorrected refractive error. Bull World Health Organ. 2009.

17. Frick K, Joy S, Wilson D, Naidoo K, Holden B. The Global Burden of Potential Productivity Loss from Uncorrected Presbyopia. Ophthalmology. 2015;122:1706-10.

18. Ma X, Zhou Z, Yi H, Pang X, Shi Y, Chen Q, et al. Effect of providing free glasses on children's educational outcomes in China: cluster randomized controlled trial. BMJ. 2014;349:g5740. 
19. Hannum E, Zhang Y. Poverty and Proximate Barriers to Learning: Vision Deficiencies, Vision Correction and Educational Outcomes in Rural Northwest China. World Dev NIH Public Access. 2012;40:1921-31.

20. Nie J, Pang X, Wang L, Rozelle S, Sylvia S. Seeing is believing: Experimental evidence on the impact of eyeglasses on academic performance, aspirations, and dropout among junior high school students in rural China. Econ Dev Cult Change. 2020;68:335-55.

21. Burton M, Ramke J, Marques A, Bourne R, Congdon N, Jones I, et al. The Lancet Global Health Commission on Global Eye Health: vision beyond 2020. Lancet Glob Heal. 2021;9:e489-551.

\section{Figures}

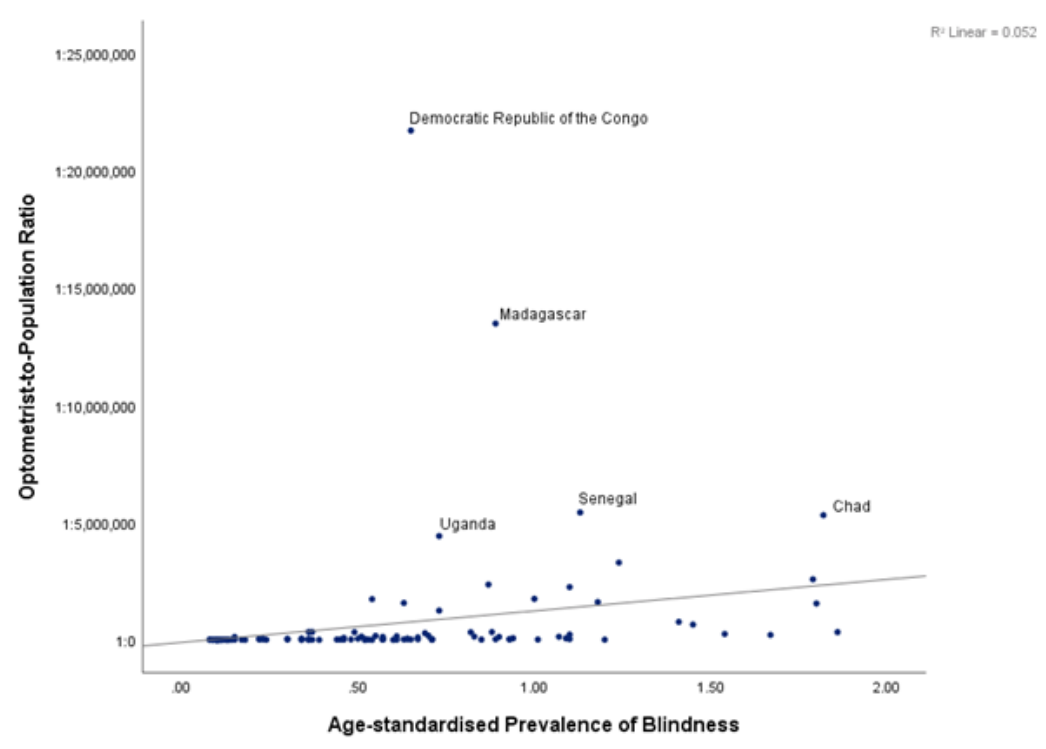

\section{Figure 1}

The relationship between the optometrist-to-population ratio and the age-standardised prevalence of blindness

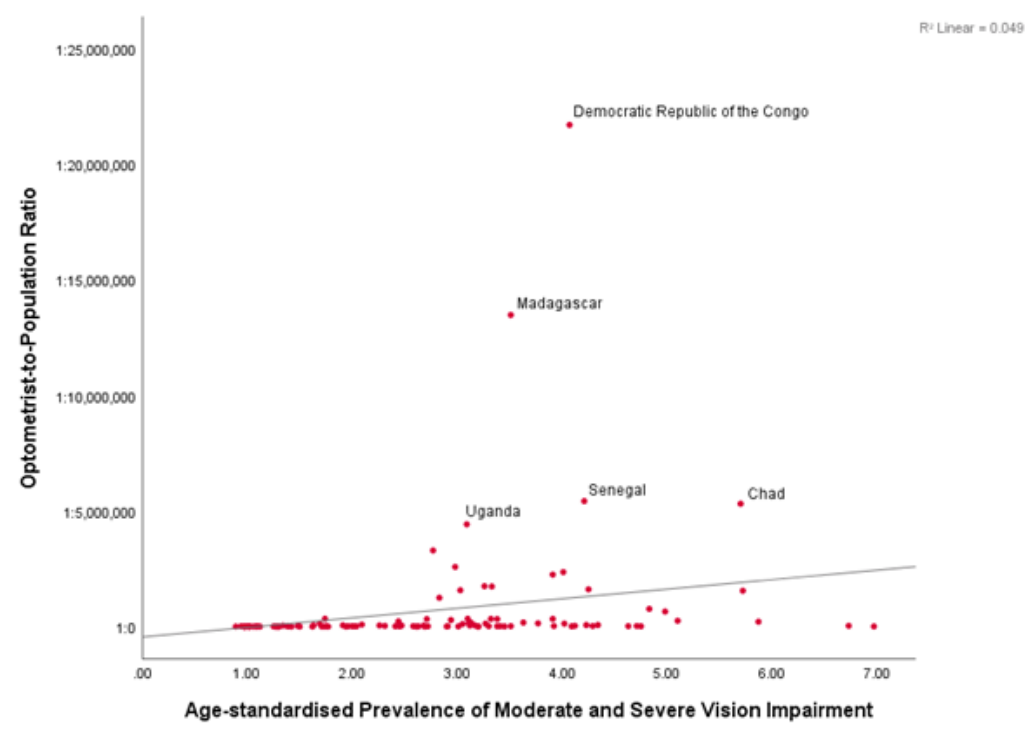

Figure 2

The relationship between the optometrist-to-population ratio and the age-standardised prevalence of mild and severe vision impairment 


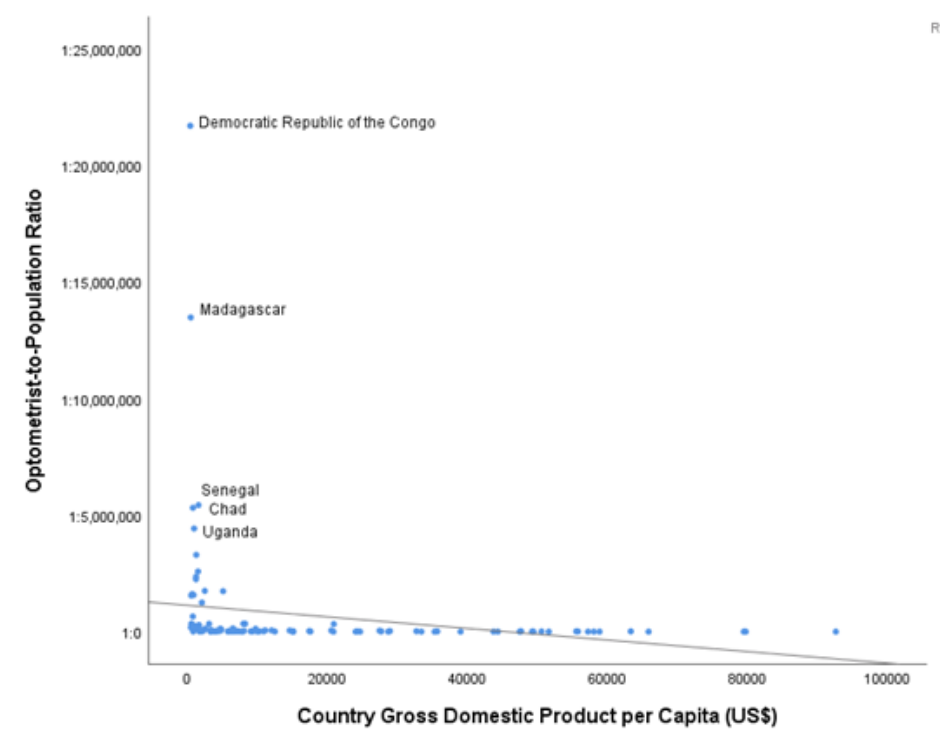

Figure 3

The relationship between the optometrist-to-population ratio and the country gross domestic product per capita

\section{Supplementary Files}

This is a list of supplementary files associated with this preprint. Click to download.

- Supplementaryfile1GBDcountriesandregions.docx

- Supplementaryfile2Countrylevelmapping.docx 